\title{
The importance of colonoscopy bowel preparation for the detection of colorectal lesions and colorectal cancer prevention
}

(1) $\odot \ominus$

\author{
Authors \\ Institutions \\ 1 University of Kansas Medical Center, Kansas City, \\ Kansas, United States \\ 2 Cleveland Clinic, Cleveland, Ohio, United States \\ 3 Eastern Virginia Medical School, Norfolk, Virginia, \\ United States \\ 4 University of Texas Health Science Center, Houston, \\ Texas, United States
}

Prateek Sharma1 , Carol A. Burke², David A. Johnson ${ }^{3}$, Brooks D. Cash ${ }^{4}$ submitted 4.9.2019

accepted after revision 31.12 .2019

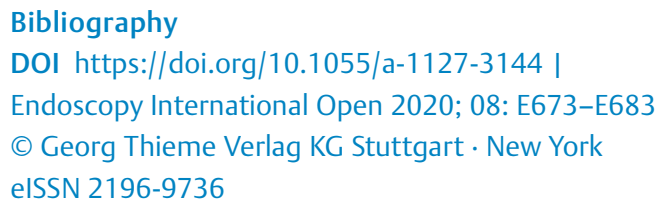

\section{Corresponding author}

Prateek Sharma, MD, Professor of Medicine, Department of Gastroenterology, Hepatology and Motility, University of Kansas School of Medicine and Veteran Affairs Medical Center, 3901 Rainbow Blvd, Kansas City, KS 66160

Fax: +1-816-922-4692

PSharma@kumc.edu

\section{ABSTRACT}

Background and study aims Colonoscopy for colorectal cancer (CRC) screening has reduced CRC incidence and mortality and improved prognosis. Optimal bowel prepara- tion and high-quality endoscopic technique facilitate early CRC detection.

This review provides a narrative on the clinical importance of bowel preparation for colonoscopy and highlights available bowel preparations.

Methods A PubMed search was conducted through June 2019 to identify studies evaluating clinical outcomes, efficacy, safety, and tolerability associated with bowel preparation for CRC screening-related colonoscopy.

Results Selecting the optimal bowel preparation regimen is based on considerations of efficacy, safety, and tolerability, in conjunction with individual patient characteristics and preferences. Available bowel preparations include high-volume $(4 \mathrm{~L})$ and low-volume $(2 \mathrm{~L}$ and $1 \mathrm{~L})$, polyethylene glycol (PEG) solutions, sodium sulfate, sodium picosulfate/magnesium oxide plus anhydrous citric acid, sodium phosphate tablets, and the over-the-counter preparations magnesium citrate and PEG-3350. These preparations may be administered as a single dose on the same day or evening before, or as two doses administered the same day or evening before/morning of colonoscopy. Ingesting at least half the bowel preparation on the day of colonoscopy (split-dosing) is associated with higher adequate bowel preparation quality versus evening-before dosing (odds ratio [OR], 2.5; $95 \%$ confidence interval [CI], 1.9-3.4).

Conclusions High-quality bowel preparation is integral for optimal CRC screening/surveillance by colonoscopy. Over the last 30 years, patients and providers have gained more options for bowel preparation, including low-volume agents with enhanced tolerability and cleansing quality that are equivalent to $4 \mathrm{~L}$ preparations. Split-dosing is preferred for achieving a high-quality preparation.

\section{Introduction}

Colorectal cancer (CRC) is the second leading cause of cancerrelated mortality in American men and women [1]. It is estimated that CRC-related deaths in the United States will exceed 51,000 in 2019 [1]. Five-year survival for patients diagnosed with localized CRC is $90 \%$; however, only $39 \%$ of patients with CRC are diagnosed at that stage [1]. Tumor location is also an important factor, as survival rates are lower for patients with tumors in the proximal colon versus the distal colon and rectum, based on a meta-analysis of 66 studies (pooled hazard ratio [HR], 0.82; $95 \%$ confidence interval [Cl], 0.79-0.84) [2].

Colonoscopy is considered the "gold standard" among CRC screening tests and is both diagnostic and therapeutic [3-5]. A critical component of a successful colonoscopy is adequate bowel preparation. It has been noted that the CRC risk reduc- 
tion associated with screening colonoscopy generally has been lower for proximal cancers compared with distal cancers [611]. One of the hypotheses for this observation is that flat and serrated lesions, which are more common in the proximal colon, may be missed due to suboptimal bowel preparation. This narrative review discusses data on the impact of bowel preparation on colonoscopy quality and describes characteristics of currently available bowel preparation options.

\section{Importance of colorectal cancer screening}

Premalignant lesions that progress to CRC include conventional adenomas and sessile serrated polyps (SSPs) [12-14]. Because early-stage CRC is typically asymptomatic, screening is required to identify premalignant and malignant colorectal neoplasia, ideally at an early, curable stage [13]. Evidence from multiple studies supports the efficacy of colonoscopy for decreasing CRC incidence, as well as improving the prognosis and reducing mortality rates $[4-8,10,11,15,16]$.

In the United States, the CRC-related mortality rate declined by more than $50 \%$ from 1970 to 2016 [1], mostly as a result of increased CRC screening and polyp removal [12]. Whereas changes before 2000 are attributable to reductions in risk factors and the increased use of screening, more recent declines are primarily attributable to the increased use of colonoscopy $[17,18]$. Guidelines from the US Preventive Services Task Force [19] and the US Multi-Society Task Force of Colorectal Cancer (MSTF) [20] recommend that asymptomatic, average-risk individuals initiate routine screening at 50 years of age. However, the American Society for Gastrointestinal Endoscopy and the American College of Gastroenterology suggest initiating CRC screening at 45 years for African Americans [20,21]. More recently, the 2018 American Cancer Society guidelines provided a qualified recommendation to initiate CRC screening at age 45 years in all individuals [22], based on data showing the rising incidence of CRC among adults aged $<50$ years [23-25].

In 2012, $27.7 \%$ of individuals between ages 50 and 75 years who were eligible for routine CRC screening in the United States had never undergone screening [26]. One retrospective community-based study showed that a significantly lower percentage of patients scheduled for screening colonoscopy attended the procedure, compared with patients scheduled for surveillance or diagnostic colonoscopy ( $45.5 \%$ vs $65.3 \%$, respectively; $P<0.0001)$ [27]. Results of a survey of individuals between ages 50 and 75 years (68\% of whom had previously undergone CRC screening) showed that the most common patient barriers to CRC screening included fear (10.1\%), unpleasantness of the bowel preparation (7.9\%), lack of awareness of or knowledge regarding CRC screening (7.9\%), pain (7.6\%), and economic limitations (6.0\%) [28].

\section{Importance of adenoma detection rates}

The adenoma detection rate (ADR) is the most important quality benchmark for screening colonoscopy [29]. For average-risk patients aged $\geq 50$ years, it is defined as the percentage of screening colonoscopies performed by an endoscopist in which one or more adenomas are found [29,30]. Prevalence of adenomas varies by patient age (higher in older patients) and sex (higher in men), with the minimum recommended ADR target of $\geq 30 \%$ in men and $20 \%$ in women [29,31]. ADR is inversely associated with the incidence and mortality of postcolonoscopy or "interval" CRC $[32,33]$. Interval CRC is cancer that occurs in an individual prior to the time interval recommended for the next CRC screening test. In one study, up to $9 \%$ of individuals with CRC had previous exposure to colonoscopy, often within the past 3 years [34].

During the last decade, large screening studies have confirmed that a higher ADR is significantly associated with a lower risk of CRC and mortality from the disease [32, 33, 35]. A 2010 study (> 45,000 patients; median follow-up, 52.1 months) reported that the risk of interval CRC was inversely associated with ADR [32]. The HR for developing CRC for an ADR between $15 \%$ to $19.9 \%$ compared with an ADR of $20 \%$ of more was 12.5 (95\% Cl, 1.5-103.4; $P=0.02$ ) [32]. A landmark 2014 study evaluated $>260,000$ colonoscopies and demonstrated that endoscopists with ADRs in the highest quintile (>33.5\%) had lower risks for patients developing interval CRC $(\mathrm{HR}=0.52 ; 95 \% \mathrm{Cl}$, 0.39-0.69), including advanced-stage interval CRC ( $H R=0.43$; $95 \% \mathrm{Cl}, 0.29-0.64)$ and fatal interval CRC $(\mathrm{HR}=0.38 ; 95 \% \mathrm{Cl}$, $0.22-0.65)$, compared with endoscopists who had ADRs in the lowest quintile (<19.1\%) [33]. For every increase of $1 \%$ in ADR, the risk of interval CRC was reduced by $3 \%$, and the risk of fatal CRC was reduced by $5 \%$ [33]. Similarly, an analysis that used community-based healthcare system data noted that for every $5 \%$ increase in ADR, the lifetime incidences of CRC risk and mortality were $11.4 \%$ and $12.8 \%$ lower, respectively [35].

\section{Quality of bowel preparation}

Given the important relationship between ADR and CRC risk, effective bowel preparation before colonoscopy is essential for optimizing the detection of colorectal neoplasia, and adequate bowel preparation is an important quality metric for colonoscopy (> Fig. 1) [29, 30].

For this narrative review, a search of the PubMed database was conducted to identify English-language publications available through June 2019, using the following keywords: "colon cancer," "colorectal cancer," "colorectal carcinoma," "colonoscopy," "colorectal cancer screening," "bowel preparation," "quality," "bowel preparation scales," "adenoma detection," "polyethylene glycol," "PEG," “sodium phosphate," "sodium sulfate," "PEG-3350," "PEG-3550," “magnesium citrate," “polyethylene glycol plus ascorbate," "PEG plus ascorbate," "NER1006," “sodium picosulfate," "efficacy," "safety," "adverse events," "tolerability," and "preference." Article bibliographies were reviewed to identify additional publications.

\section{Bowel preparation quality scales}

Several scales have been developed to assess the quality of bowel preparation ( $>$ Table $\mathbf{1}$ and $\triangleright$ Table 2 ) in the various segments of the colon ( $\triangleright$ Fig. 2) [36-42]. The Aronchick Scale - the first scale introduced for evaluating bowel preparation quality uses an overall rating for the entire colon on a five-point scale from "inadequate" to "excellent" [37]. The Harefield Cleansing Scale involves the analysis of five colon segments using a fivepoint segmental scale (range, 0 [irremovable, heavy, hard 


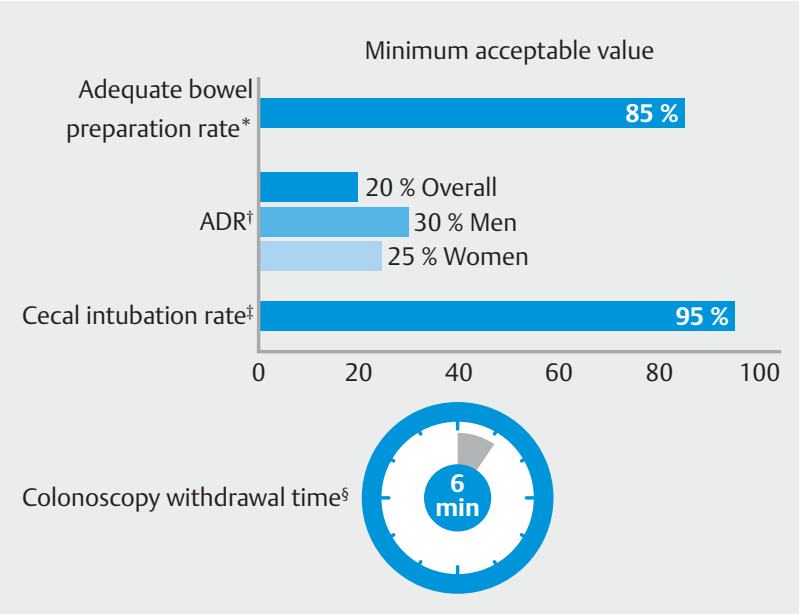

- Fig. 1 Select colonoscopy quality indicators [29].

$A D R$, adenoma detection rate.

" Rate at which outpatient bowel preparation is suitable for using recommended surveillance or screening intervals.

$\dagger$ Percentage of screening colonoscopies performed in average-risk asymptomatic individuals aged $\geq 50$ years in which $\geq 1$ adenoma has been detected.

$\ddagger$ Percentage of screening colonoscopies with successful cecal intubation and photographic evidence of cecal landmarks.

$\S$ Average withdrawal time in screening colonoscopies with negative results.

Figure created with data from Rex DK, et al. Gastrointest Endosc

2015; 81: 31-53.

stools] to 4 [empty and clean]). Overall cleansing success is assessed using a four-grade system (i.e., A [high-quality] to $D$ [failure], with grade A requiring all five segments to have scores of 3 or 4) [41]. Although the Aronchick Scale is widely used, it has not been formally validated or shown to correlate with clin- ical outcomes. The Harefield Cleansing Scale is validated; an increasing body of clinical outcomes evidence indicates that it is particularly useful for rigorous clinical studies.

The Ottawa Bowel Preparation Scale was designed as a research tool for evaluating differences between bowel preparations and regimens [36] and consists of ratings for three colon segments (i. e., right, mid, recto-sigmoid) on a five-point scale and an overall rating of the amount of fluid in the colon [38, 39].

The Boston Bowel Preparation Scale consists of ratings for three colon segments on a four-point scale [40, 43]. A systematic review found the Boston Bowel Preparation Scale to be the most thoroughly validated and clinically relevant scale [36]. The Chicago Bowel Preparation Scale, introduced in 2013, was developed most recently. It rates the cleanliness of the right, transverse, and left colon segments on a scale from 0 to 12 , for a total cleanliness score of 0 (very poor) to 36 (outstanding) [42]. Scoring is performed after washing or suctioning the colonic mucosa. Further, the total fluid volume in the colon is precisely quantified and scored [42]. The Chicago Bowel Preparation Scale is not as widely used or suitable for routine practice as is the Boston Bowel Preparation Scale [36].

\section{Clinical importance of adequate bowel preparation}

Studies have reported that bowel preparation is inadequate in $15 \%$ to $35 \%$ of colonoscopies, with rates varying across medical settings and patient populations [44-50]. Inadequate bowel preparation negatively impacts the ADR and other indicators of colonoscopy quality (e. g., cecal intubation rates), lengthens procedure times (e. g., increased time washing and suctioning debris, prolonged withdrawal time), and results in shorter surveillance intervals and increased costs $[44,46,49,51-60]$. A pooled analysis of eight prospective studies $(n=9167)$ found that metachronous CRC was diagnosed in $0.6 \%$ of patients

- Table 1 Bowel preparation grading scales assessing quality across the length of the colon [36-42]

\begin{tabular}{|c|c|c|c|}
\hline Points & Aronchick Scale & $\begin{array}{l}\text { Chicago Bowel } \\
\text { Preparation Scale }\end{array}$ & $\begin{array}{l}\text { Ottawa Bowel } \\
\text { Preparation Scale }\end{array}$ \\
\hline 0 & - & Little fluid ( $\leq 50 \mathrm{cc}$ ) & Small amount of fluid \\
\hline 1 & $\begin{array}{l}\text { Excellent: small volume of clear liquid or }>95 \% \text { of surface } \\
\text { seen }\end{array}$ & $\begin{array}{l}\text { Minimal amount of fluid } \\
(51-150 \mathrm{cc})\end{array}$ & Moderate amount of fluid \\
\hline 2 & $\begin{array}{l}\text { Good: large volume of clear liquid covering } 5 \% \text { to } 25 \% \text { of } \\
\text { the surface but greater than } 90 \% \text { of surface seen }\end{array}$ & $\begin{array}{l}\text { Moderate amount of fluid } \\
(151-300 \mathrm{cc})\end{array}$ & Large amount of fluid \\
\hline 3 & $\begin{array}{l}\text { Fair: some semi-solid stool that could be suctioned or } \\
\text { washed away, but }>90 \% \text { of surface seen }\end{array}$ & Large amount of fluid (>300 cc) & - \\
\hline 4 & $\begin{array}{l}\text { Poor: semi-solid stool that could not be suctioned or } \\
\text { washed away, and }<90 \% \text { of surface seen }\end{array}$ & - & - \\
\hline 5 & Inadequate: repeat preparation needed & - & - \\
\hline $\begin{array}{l}\text { Total score } \\
\text { ranges }\end{array}$ & 1 (excellent) to 5 (inadequate) & $\begin{array}{l}0 \text { (little fluid) to } 3 \text { (large amount } \\
\text { of fluid) }\end{array}$ & $\begin{array}{l}0 \text { (small amount of fluid) to } 2 \\
\text { (large amount of fluid) }\end{array}$ \\
\hline
\end{tabular}


- Table 2 Bowel preparation grading scales assessing quality by colonic segment [36-42]

\begin{tabular}{|c|c|c|c|c|}
\hline Points & $\begin{array}{l}\text { Boston Bowel Preparation } \\
\text { Scale }\end{array}$ & $\begin{array}{l}\text { Chicago Bowel Preparation } \\
\text { Scale }\end{array}$ & $\begin{array}{l}\text { Harefield Cleansing } \\
\text { Scale }\end{array}$ & $\begin{array}{l}\text { Ottawa Bowel Preparation } \\
\text { Scale }\end{array}$ \\
\hline 0 & $\begin{array}{l}\text { Unprepared colon segment with } \\
\text { stool that cannot be cleared }\end{array}$ & $\begin{array}{l}\text { Unprepared colon segment with } \\
\text { stool that cannot be cleared } \\
\text { (>15\% of mucosa not seen) }\end{array}$ & Unremovable, heavy, hard stools & $\begin{array}{l}\text { Excellent: mucosal detail clearly } \\
\text { visible }\end{array}$ \\
\hline 1 & $\begin{array}{l}\text { Portion of mucosa in segment } \\
\text { seen after cleaning, but other } \\
\text { areas not seen because of re- } \\
\text { tained material }\end{array}$ & - & $\begin{array}{l}\text { Semisolid, only partially remova- } \\
\text { ble stools }\end{array}$ & $\begin{array}{l}\text { Good: minimal turbid fluid in } \\
\text { segment }\end{array}$ \\
\hline 2 & $\begin{array}{l}\text { Minor residual material after } \\
\text { cleaning, but mucosa of segment } \\
\text { generally well seen }\end{array}$ & - & $\begin{array}{l}\text { Brown liquid/fully removable } \\
\text { semi-solid stools }\end{array}$ & $\begin{array}{l}\text { Fair: necessary to suction liquid } \\
\text { to adequately view segment }\end{array}$ \\
\hline 3 & $\begin{array}{l}\text { Entire mucosa of segment well } \\
\text { seen after cleaning }\end{array}$ & - & Clear liquid & $\begin{array}{l}\text { Poor: necessary to wash and suc- } \\
\text { tion to obtain a reasonable view }\end{array}$ \\
\hline 4 & - & - & Empty and clean & $\begin{array}{l}\text { Inadequate: solid stool not } \\
\text { cleared with washing and suc- } \\
\text { tioning }\end{array}$ \\
\hline 5 & - & $\begin{array}{l}\text { Some of mucosa in segment seen } \\
\text { after cleaning, but } \leq 15 \% \text { of mu- } \\
\text { cosa not seen due to retained } \\
\text { material }\end{array}$ & - & - \\
\hline 10 & - & $\begin{array}{l}\text { Minor residual material after } \\
\text { cleaning, but mucosa of segment } \\
\text { generally well seen }\end{array}$ & - & - \\
\hline 11 & - & $\begin{array}{l}\text { Entire mucosa of segment well } \\
\text { seen after washing }\end{array}$ & - & - \\
\hline 12 & - & $\begin{array}{l}\text { Entire mucosa of segment well } \\
\text { seen without washing }\end{array}$ & - & - \\
\hline $\begin{array}{l}\text { Seg- } \\
\text { ments } \\
\text { scored }\end{array}$ & $\begin{array}{l}\text { Right colon; transverse colon, in- } \\
\text { cluding hepatic and splenic flex- } \\
\text { ures; left colon }\end{array}$ & $\begin{array}{l}\text { Right colon; transverse colon; } \\
\text { left colon }\end{array}$ & $\begin{array}{l}\text { Cecum and ascending colon; } \\
\text { transverse colon; descending } \\
\text { colon; sigmoid colon; rectum }\end{array}$ & $\begin{array}{l}\text { Right colon (cecum and ascend- } \\
\text { ing colon); mid colon (transverse } \\
\text { and descending colon); rectosig- } \\
\text { moid colon }\end{array}$ \\
\hline $\begin{array}{l}\text { Scoring } \\
\text { ranges }\end{array}$ & $\begin{array}{l}\text { Each segment score: } 0 \text { to } 3 \\
\text { Total score: } 0 \text { (unprepared colon) } \\
\text { to } 9 \text { (clean colon) }\end{array}$ & $\begin{array}{l}\text { Each segment score: } 0 \text { to } 12 \\
\text { Total score: } 0 \text { (very poor) to } 36 \\
\text { (outstanding) }\end{array}$ & $\begin{array}{l}\text { Successful: } \\
\text { A: all segments with score } 3 \text { or } 4 \\
\text { B: } \geq 1 \text { segment with score } \\
\quad 2 \text { Unsuccessful: } \\
C: \geq 1 \text { segment with score } 1 \\
D: \geq 1 \text { segment with score } 0\end{array}$ & $\begin{array}{l}\text { Each segment score: } 0 \text { to } 4 \\
\text { Whole colon fluid score: } 0 \text { to } 2 \\
\text { Total score: } 0 \text { (perfect) to } 14 \\
\text { (completely unprepared colon) }\end{array}$ \\
\hline
\end{tabular}

Table created with data from Parmar R, et al. Am J Gastroenterol 2016; 111: 197-204; Aronchick CA, et al. Gastrointest Endosc 2000; 52: 346-352; Rostom A, Jolicoeur E. Gastrointest Endosc 2004; 59: 482-486; Saltzman JR et al. Gastrointest Endosc 2015; 81: 781-794; Lai EJ, et al. Gastrointest Endosc 2009; 69: 620-625; Halphen M, et al. Gastrointest Endosc 2013; 78: 121-131; Gerard DP, et al. Clin Transl Gastroenterol 2013; 4: 1-11.

who had a preceding normal colonoscopy, yielding an interval CRC incidence rate of 1.7 per 1000 person-years of follow-up; lesions missed at screening were predicted to account for $51.7 \%$ of interval CRCs [61]. Compared with screen-detected cancer, interval CRCs are more likely to occur in the proximal colon [62-65]. A meta-analysis of 12 studies calculated that interval CRC cases, compared with detected CRC cases, were 2.4 times more likely to occur in the proximal colon versus the distal colon [66]. In a pooled analysis of the eight studies noted above [61], 29 (50.0\%) of the 58 interval CRCs were proximal to the splenic flexure and significantly more likely to be missed (as indicated by occurrence of CRC within 3 years of a prior co- lonoscopy in which there was no evidence of significant adenoma in the involved segment) than left-sided interval CRCs (65.5\% vs $37.9 \%$, respectively; $P=0.04$ ).

Guidelines from the MSTF recommend repeat colonoscopy within 1 year for patients with inadequate bowel preparation [67]. Adequate bowel preparation is important for high-quality screening colonoscopy, for maximizing the efficacy of the exam in the proximal colon [68], and also for identifying lesions that are more difficult to detect [69]. These factors are likely interrelated, because the predominance of SSPs and other flat and depressed lesions is greater in the proximal colon $[68,69]$. 


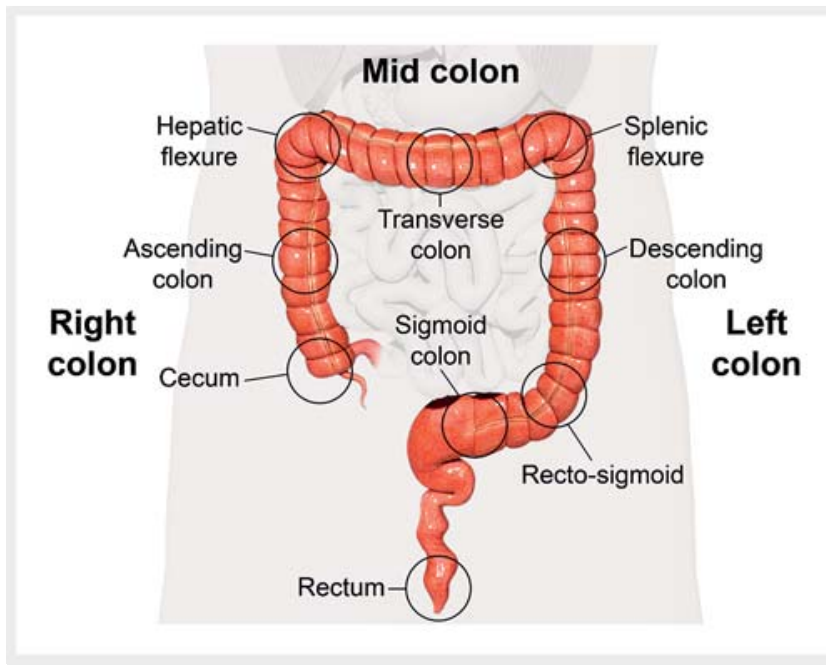

Fig. 2 Colon anatomy.

Quality of bowel preparation has been associated with ADRs in multiple studies [46, 49, 50,70-74]. A retrospective study of screening colonoscopies at an academic medical center reported a per-adenoma miss rate (defined as the number of adenomas found on repeat examination divided by the sum of the number of adenomas identified on initial and repeat examination) of $47.9 \%$ in 373 patients with inadequate bowel preparation [72]. Similarly, a retrospective study at a hospital-based endoscopy unit found a miss rate of $41.9 \%$ for all adenomas and $27.5 \%$ for advanced adenomas in patients with suboptimal (poor or fair) bowel preparation [46]. A meta-analysis showed that, compared with low-quality bowel preparations, ADRs were significantly greater with intermediate (odds ratio [OR], 1.4; $95 \% \mathrm{Cl}, 1.1-1.8)$ and high-quality bowel preparations (OR, 1.4; $95 \% \mathrm{Cl}, 1.2-1.6)$ [70]. Based on the relationship between inadequate bowel preparation and decreased ADR, it is plausible that improving bowel preparation quality might reduce risk of interval CRC.

Inadequate bowel preparation is also associated with incomplete screening colonoscopy [49]. Further, excellent bowel preparation quality was significantly associated with shorter cecal intubation time (5.7 minutes) versus that for good (6.9 minutes), fair (7.6 minutes), or poor bowel preparation quality (7.4 minutes; $P<0.001$ for comparisons of different bowel preparation qualities) [75].

\section{Factors that affect bowel preparation quality}

A number of product- and patient-related factors may impact the quality of bowel preparation ( $\bullet$ Table 3 ) $[67,76-84]$, including comorbid conditions and the use of certain pharmacologic agents $[85,86]$. A retrospective single-center study $(n=$ 404) of patients undergoing a screening or diagnostic colonoscopy reported that those with diabetes had a significantly increased risk of poor-quality bowel preparation compared with those without diabetes (OR, 3.5; $95 \% \mathrm{Cl}, 1.4-8.7)$ [86]. This study also found that patients with fewer than three bowel movements per week were at significantly greater risk of poor-
- Table 3 Factors that can improve bowel preparation quality $[67,76-84]$.

\begin{tabular}{|l|l|}
\hline Product-related factors & Patient-related factors \\
\hline Tolerability & Adherence to instructions \\
\hline - Low preparation volume & - Patient education \\
\hline - Adequate palatability & - Health literacy \\
\hline $\begin{array}{l}\text { Dosing regimen } \\
\text { - Split-dosing (2-day or same } \\
\text { day of colonoscopy) }\end{array}$ & - Motivation \\
\hline $\begin{array}{l}\text { Timing of administration } \\
\text { - Final dose completed within } 2 \\
\text { to } 5 \text { hours before the start of } \\
\text { the procedure }\end{array}$ \\
\hline
\end{tabular}

Table created with data from Johnson DA, et al. Gastroenterology 2014; 147: 903-924; Guo X, et al. Gastrointest Endosc 2017; 85: 90 -97 e96; Mamula P, et al. Gastrointest Endosc 2009; 69: 1201-1209; Smith SG, et al. Dis Colon Rectum 2012; 55: 1074-1080; Cipolletta L, Rotondano G. Dig Liver Dis 2013; 45: 16-17; Kilgore TW, et al. Gastrointest Endosc 2011; 73: 1240-1245. Martel M, et al. Gastroenterology 2015; 149: 79-88; Horton N, et al. Am J Gastroenterol 2016; 111: 1330-1337; Avalos DJ, et al. J Clin Gastroenterol 2017; 52: 859-868; Seo EH, et al. Gastrointest Endosc 2012; 75: 583-590.

quality bowel preparation compared with patients with 3 to 14 bowel movements per week (OR, 5.2; $95 \% \mathrm{Cl}, 1.8-15.2)$ [86]. These findings were consistent with data from a meta-analysis of 38 studies $(n=36,860)$ that noted a significant association between constipation and poor-quality bowel preparation (OR, 1.6; 95\% Cl, 1.3-1.9) [85]. Another meta-analysis determined that use of opioids (12 studies; $n=13,039$ ) and tricyclic antidepressants ( 10 studies; $n=11,461$ ) also significantly increased the odds of poor-quality bowel preparation (opioids: OR, 1.7; $95 \% \mathrm{Cl}, 1.4-2.1$; tricyclic antidepressants: OR, 2.0; $95 \% \mathrm{Cl}, 1.4-2.9)$ [85].

Noncompliance to dosing instructions has been shown to be a strong predictor of suboptimal bowel preparation (OR, 6.7; $95 \% \mathrm{Cl}, 3.2-14.2$ ) [87]. An analysis of average-risk patients who underwent routine screening colonoscopy showed that $86.7 \%$ of patients with poor bowel preparation had either failed to complete the preparation or failed to follow the written instructions on timing of preparation or dietary restrictions [48]. A meta-analysis of randomized studies reported that enhanced patient education was associated with greater dosing instruction adherence and higher-quality bowel preparation [76]. Several patient characteristics associated with inadequate bowel preparation (e.g., older age, lower education level, Medicaid insurance) $[47,88]$ may serve as proxies for lower health litera$c y$, which highlights the importance of providing bowel preparation instructions that are easy to understand $[78,89]$, as well as clearly explaining to patients why it is important to complete the preparation as instructed.

Tolerability is strongly affected by characteristics of the bowel preparation product and the regimen for administration [90]. The requirement of a high volume of bowel preparation is identified by patients as a deterrent to participation in screening colonoscopies [91]. Low-volume and split-dose regimens are associated with improved tolerability [67], but adverse effects from low-volume bowel preparations, including dehydration, hyponatremia, and other fluid and electrolyte imbalance- 
related hospitalizations, are more common than with high-volume preparations $[92,93]$. Elderly patients or patients with impaired renal function should be monitored closely. Carbohydrate-electrolyte rehydration solutions (e.g., sports drinks) may be contraindicated in patients with diabetes, as well as in those with renal insufficiency, due to the risks of hyperglycemia and potassium overload, respectively [93].

Split-dosing, with at least $50 \%$ of the bowel preparation consumed on the day of the exam, is recognized as superior in both efficacy and tolerability compared with day-before dosing [67, 94]. A meta-analysis of five randomized trials reported that split-dosing of $4 \mathrm{~L}$ polyethylene glycol (PEG), compared with day-before dosing, increased the number of adequate bowel preparations (OR 3.7; $95 \% \mathrm{Cl}, 2.8-4.9$ ), patient willingness to repeat the preparation for a subsequent colonoscopy (OR 1.8; $95 \% \mathrm{Cl}, 1.1-2.9$ ), and decreased incidence of nausea (OR 0.6; $95 \% \mathrm{Cl}, 0.4-0.8$ ) [80]. Similarly, another meta-analysis reported that split-dosing increased the likelihood of an adequate bowel preparation ( $n=32$ studies; OR 2.5; $95 \% \mathrm{Cl}, 1.9-3.4$ ) and patient willingness to repeat the preparation ( $\mathrm{n}=14$ studies; OR 1.9; $95 \% \mathrm{Cl}, 1.0-3.5$ ) [81]. The efficacy of same-day bowel preparation is supported by a meta-analysis of 15 randomized studies, which noted similar bowel preparation quality (relative risk [RR], 0.95, 95\% Cl, 0.90-1.00), ADR (RR, 0.97; $95 \% \mathrm{Cl}, 0.79-1.20)$, and patient willingness to repeat the process ( $R R, 1.14 ; 95 \% \mathrm{Cl}, 0.96-1.36)$ for same-day compared with split-dosing [83].

Regarding the timing between preparation and procedure ("runway time"), the likelihood of suboptimal preparation is increased for colonoscopies scheduled later in the day (OR, 1.9; $95 \% \mathrm{Cl}, 1.7-2.1)$ [47]; this situation may be a function of the longer time between the consumption of the bowel preparation and the procedure [95]. A prospective analysis of 378 consecutive outpatients from a single practice found that every hour a patient waited between the last preparation dose and the start of colonoscopy translated to a nearly $10 \%$ decline in the likelihood of receiving a good or excellent bowel preparation quality rating [95]. Thus, a shorter runway time may increase the chance of a good or excellent bowel preparation, which may, in turn, improve detection of colorectal neoplasia. A prospective observational study determined that 3 to 5 hours between the last dose of PEG and the start of the colonoscopy was the time frame that provided the best bowel preparation quality [84]. Guidelines strongly recommend split-dose bowel preparation, with same-day preparation as an alternative to 2day split-dosing, particularly for patients who schedule an afternoon colonoscopy, with the last bowel preparation dose beginning 4 to 6 hours before and completed $\geq 2$ hours before the procedure time [67].

\section{Bowel preparation regimens}

Selecting the optimal bowel preparation regimen is based on considerations of efficacy, safety, and tolerability, in conjunction with individual patient characteristics and preferences $[90,96]$. Innovations in bowel preparation formulations were introduced to improve efficacy, tolerability, and safety [97]. Characteristics of the ideal bowel preparation include excellent efficacy for removing residual stool from the colon without affecting mucosal morphology or plasma fluid and electrolyte homeostasis, superior tolerability (in terms of palatability and adverse event $[A E]$ profile), and safety, as well as being reasonably priced and simple to administer $[97,98]$. Available bowelcleansing agents differ by their mechanism of action and volume requirements ( $\triangleright$ Table 4 ) [39, 90, 97, 99-110]. PEG agents are isotonic and act by retaining fluid within the lumen of the colon and small bowel [97]. In contrast, hypertonic reagents (eg, sodium phosphate tablets) induce paracellular fluid shifts toward the lumen of the colon and small bowel [97].

Introduced in the early 1980 s, the US Food and Drug Administration (FDA) - approved PEG electrolyte solution became the most commonly used agent for bowel preparation because of its favorable safety profile $[108,111]$. However, $5 \%$ to $15 \%$ of patients do not ingest the recommended amount, primarily due to the large volume $(4 \mathrm{~L})$ and poor palatability $[39,112]$. High-volume PEG with a balanced electrolyte solution is recommended for patients with chronic constipation or previous inadequate bowel preparation and is needed for patients who cannot tolerate fluid or electrolyte shifts (e.g., patients with congestive heart failure or hepatic or renal failure) [109]. To address palatability issues, the potassium concentration was reduced and the sodium sulfate was removed to produce a $4-\mathrm{L}$ sulfate-free PEG, which was considered more palatable and exhibited efficacy similar to the initial PEG preparations [39, 109]. However, tolerability remained suboptimal due to the large volume requirement. Thus, low-volume bowel preparation options - such as PEG plus ascorbate $(2 \mathrm{~L}$ and $1 \mathrm{~L})$, oral sodium sulfate, and sodium picosulfate plus magnesium oxide and anhydrous citric acid - have been developed and approved ( $>$ Table 4).

An over-the-counter PEG product for the management of constipation (PEG-3550) has also been used for colonoscopy preparation [90,107]. A 2013 survey of gastroenterologists revealed that more than one-third recommended PEG-3550 as a bowel preparation to patients, primarily in suburban settings [113]. PEG-3550 is not osmotically balanced, and electrolyte shifts, particularly hyponatremia, may occur, which could cause complications in patients with certain comorbidities [109]. Efficacy results with PEG-3550 have been mixed when compared with FDA-approved products [90,109].

The FDA has approved two low-volume PEG products: a 2-L formulation approved in 2006 [101], and a $1 \mathrm{~L}$ formulation (NER1006) approved in 2018 [102]. Both preparations are formulated with ascorbic acid and sodium ascorbate, which enhance the osmotic effect and may improve palatability [108]. In healthy individuals without constipation, low-volume PEG formulations provide bowel-cleansing effectiveness similar to that of 4 L PEG [67]. In a 2014 meta-analysis of 11 randomized, controlled studies, the efficacy of $2 \mathrm{~L}$ PEG plus ascorbate was comparable to that of 4-L PEG, with improved tolerability and fewer adverse effects [114].

Unlike the 2-L PEG plus ascorbate, the bowel preparation NER1006, approved by the FDA in 2018, has a unique asymmetric dosing regimen. The first dose acts primarily as a debulking agent, and the second dose provides an osmotic washout. All of the ascorbate in NER1006 is administered with the second 
- Table 4 Bowel preparation regimens [39, 90,97,99-110].

\begin{tabular}{|c|c|c|c|c|}
\hline Product & Composition & Total volume & $\begin{array}{l}\text { Indication/ } \\
\text { dosing }\end{array}$ & Most common AEs ${ }^{1}$ \\
\hline 4LPEG & $\begin{array}{l}\text { PEG-3350, sodium sul- } \\
\text { fate, sodium bicarbo- } \\
\text { nate, sodium chloride, } \\
\text { potassium chloride }\end{array}$ & $4 \mathrm{~L}(128 \mathrm{oz})$ & $\begin{array}{l}\text { Bowel cleansing before colonos- } \\
\text { copy and barium enema X-ray in } \\
\text { adults }\end{array}$ & $\begin{array}{l}\leq 50 \% \text { of patients: nausea, abdominal } \\
\text { fullness, and bloating }\end{array}$ \\
\hline 4L PEG, sulfate-free & $\begin{array}{l}\text { PEG-3550, sodium } \\
\text { bicarbonate, sodium } \\
\text { chloride, potassium } \\
\text { chloride }\end{array}$ & $4 \mathrm{~L}(128 \mathrm{oz})$ & $\begin{array}{l}\text { Bowel cleansing before colonos- } \\
\text { copy in adults and pediatric pa- } \\
\text { tients } \geq 6 \text { months of age }\end{array}$ & $\begin{array}{l}\leq 50 \% \text { of patients: nausea, abdominal } \\
\text { fullness, and bloating }\end{array}$ \\
\hline 2L PEG plus ascorbate & $\begin{array}{l}\text { PEG-3350, sodium sul- } \\
\text { fate, sodium chloride, } \\
\text { potassium chloride, so- } \\
\text { dium ascorbate, ascor- } \\
\text { bic acid }\end{array}$ & $\begin{array}{l}2 \mathrm{~L}(64 \mathrm{oz})+1 \mathrm{~L} \\
(32 \mathrm{oz}) \text { clear fluids }\end{array}$ & $\begin{array}{l}\text { Bowel cleansing before colonos- } \\
\text { copy in adults: split-dosing, } 2 \text {-day } \\
\text { or evening before (1-day) }\end{array}$ & $\begin{array}{l}\geq 2 \% \text { of patients with } 2 \text {-day dosing: } \\
\text { malaise, nausea, abdominal pain, } \\
\text { vomiting, upper abdominal pain, and } \\
\text { dyspepsia } \\
\geq 5 \% \text { of patients with evening-before } \\
\text { (1-day) dosing: abdominal distension, } \\
\text { anal discomfort, thirst, nausea, ab- } \\
\text { dominal pain, sleep disorder, rigors, } \\
\text { hunger, malaise, vomiting, and dizzi- } \\
\text { ness }\end{array}$ \\
\hline $\begin{array}{l}\text { 1 L PEG plus ascorbate } \\
\text { (NER1006) }\end{array}$ & $\begin{array}{l}\text { PEG- } 3350 \text {, sodium as- } \\
\text { corbate, sodium sulfate, } \\
\text { ascorbic acid, sodium } \\
\text { chloride, potassium } \\
\text { chloride }\end{array}$ & $\begin{array}{l}1 \mathrm{~L}(32 \mathrm{oz})+1 \mathrm{~L} \\
(32 \mathrm{oz}) \text { clear fluids }\end{array}$ & $\begin{array}{l}\text { Bowel cleansing before colonos- } \\
\text { copy in adults: split dosing, 2-day } \\
\text { or morning of (1-day) }\end{array}$ & $\begin{array}{l}>2 \% \text { of patients: nausea, vomiting, } \\
\text { dehydration, and abdominal pain/dis- } \\
\text { comfort }\end{array}$ \\
\hline Oral sodium sulfate & $\begin{array}{l}\text { Sodium sulfate, potas- } \\
\text { sium sulfate, magne- } \\
\text { sium sulfate }\end{array}$ & $\begin{array}{l}1 \mathrm{~L}(32 \mathrm{oz})+2 \mathrm{~L} \\
(64 \mathrm{oz}) \text { water }\end{array}$ & $\begin{array}{l}\text { Bowel cleansing before colonos- } \\
\text { copy in adults: split dosing, 2-day }\end{array}$ & $\begin{array}{l}\geq 2 \% \text { of patients: overall discomfort, } \\
\text { abdominal distension, abdominal } \\
\text { pain, nausea, vomiting, and headache }\end{array}$ \\
\hline $\begin{array}{l}\text { Sodium picosulfate }+ \\
\text { magnesium oxide and } \\
\text { anhydrous citric acid }\end{array}$ & $\begin{array}{l}\text { Sodium picosulfate, } \\
\text { magnesium oxide, citric } \\
\text { acid }\end{array}$ & $\begin{array}{l}320 \mathrm{~mL} \\
(10.8 \mathrm{oz})+ \\
2 \mathrm{~L}(64 \mathrm{oz}) \\
\text { clear fluids }\end{array}$ & $\begin{array}{l}\text { Bowel cleansing before colonos- } \\
\text { copy in adults: split dosing, 2-day } \\
\text { or evening-before (1-day) }\end{array}$ & $\begin{array}{l}>1 \% \text { of patients: nausea, headache, } \\
\text { and vomiting }\end{array}$ \\
\hline $\begin{array}{l}\text { Sodium phosphate } \\
\text { tablets }\end{array}$ & Sodium phosphate & $\begin{array}{l}32 \text { tablets }+ \\
2 \mathrm{~L}(64 \mathrm{oz}) \text { clear } \\
\text { fluids }\end{array}$ & $\begin{array}{l}\text { Bowel cleansing before colonos- } \\
\text { copy in adults: split dosing, 2-day }\end{array}$ & $\begin{array}{l}>3 \% \text { of patients: abdominal bloating, } \\
\text { nausea, abdominal pain, and vomiting } \\
\text { Note: black box warning noting rare } \\
\text { but serious reports of acute phos- } \\
\text { phate nephropathy }\end{array}$ \\
\hline Magnesium citrate & Magnesium citrate & $\begin{array}{l}20-30 \mathrm{oz}+ \\
2 \mathrm{~L}(64 \mathrm{oz}) \text { water }\end{array}$ & Constipation (available OTC) & $\begin{array}{l}\text { Not available in US prescribing infor- } \\
\text { mation (not FDA-approved as bowel } \\
\text { preparation) }\end{array}$ \\
\hline PEG-3350 & PEG-3350 & $2 \mathrm{~L}(64 \mathrm{oz})$ & Constipation (available OTC) & $\begin{array}{l}\text { Not available in US prescribing infor- } \\
\text { mation (not FDA-approved as bowel } \\
\text { preparation) }\end{array}$ \\
\hline
\end{tabular}

AE, adverse event; FDA, US Food and Drug Administration; OTC, over the counter; PEG, polyethylene glycol.

Table created with data from ASGE Standards of Practice Committe, Saltzman JR, et al. Gastrointest Endosc 2015; 81: 781-794; Harrison NM, Hjelkrem MC. World J Gastrointest Endosc 2016; 8: 4-12; Martens P, Bisschops R. Acta Gastroenterol Belg 2014; 77: 249-255; GoLYTELY package insert. Braintree, MA: Braintree Laboratories, Inc; 2013; NuLYTELY package insert. Braintree, MA: Braintree Laboratories, Inc; 2013; MoviPrep package insert. Bridgewater, NJ: Salix Pharmaceuticals Inc; 2016; Plenvu package insert. Amsterdam, The Netherlands: Norgine B.V.; 2019; Suprep Bowel Prep Kit package insert. Braintree, MA: Braintree Laboratories, Inc.; 2010; Prepopik package insert. Parsippany, NJ: Ferring Pharmaceuticals Inc; 2012; Osmoprep package insert. Bridgewater, NJ: Salix Pharmaceuticals, Inc.; 2016; Clenpiq package insert. Parsippany, NJ: Ferring Pharmaceuticals, Inc; 2017; MiraLAX package insert. Boca Raton, FL: Bayer; 2019; Chisholm S, et al. J Okla State Med Assoc 2015; 108: 311-317; Rutherford CC, Calderwood AH. Curr Treat Options Gastroenterol 2018; 16: 165-181;DiPalma JA, Marshall JB. Gastrointest Endosc 1990 ; $36: 285-289$.

${ }^{1}$ Most common AEs and cutoff rates provided based on reporting in the US prescribing information for bowel cleansing before colonoscopy indication.

dose. NER1006 may be taken as a split-dose using either a 2-day or a same-day (as colonoscopy) regimen, with mango- (dose 1) and fruit punch - flavored (dose 2 ) doses to improve palatability and patient adherence $[102,115]$. The efficacy and safety of NER1006 versus other bowel preparations has been evaluated in several randomized, noninferiority, phase 3 studies [115117]. Compared with the 2 L PEG plus ascorbate split-dose formulation, NER1006, administered as either a 2-day or same-day split-dose, was noninferior in bowel-cleansing efficacy and demonstrated a superior cleansing rate and polyp detection 
rate in the right colon [115]. In addition, the overall tolerability and safety profiles were similar for the two formulations [115].

In another study, NER1006 was noninferior to sodium picosulfate/magnesium oxide and anhydrous citric acid for overall colon cleansing, ascending colon/cecum cleansing, and lesion detection rates, and both preparations were well tolerated [117]. NER1006 was noninferior to oral sulfate solution for overall cleansing of the bowel and high-quality cleansing of the ascending colon, with comparable lesion detection rates, tolerability, and adherence [116]. Of note, more patients randomly assigned to NER1006 (39.3\%) than to oral sulfate solution (4.2\%) had reversible shifts in sodium levels from baseline to high (based on laboratory normal ranges at study sites) at visit 2 (day of colonoscopy). However, the increased sodium levels did not persist, and no patients required treatment for electrolyte imbalances [116]. To limit the possibility of hypernatremia and dehydration, it is recommended that patients remain adequately hydrated before, during, and after the consumption of NER1006 [116].

Sodium phosphate tablets are the only bowel preparation agent available in tablet form and are taken with approximately $2 \mathrm{~L}$ of clear fluids [105]. Although this bowel-cleansing method is efficacious and palatable, it is associated with electrolyte and fluid shifts, and there is risk for acute phosphate nephropathy in susceptible individuals (e.g., increased age, hypovolemia, active colitis, certain concomitant medications) $[105,108]$.

Oral sulfate solution includes sulfate rather than sodium phosphate to reduce the required bowel preparation volume while addressing concerns related to the fluid and electrolyte shifts associated with sodium phosphate $[103,109]$. A prospective, randomized study demonstrated that oral sodium sulfate was as effective as a $4 \mathrm{~L}$ split-dose PEG and had better patient acceptance, tolerability, and satisfaction [118]. Another prospective, randomized study showed that a greater percentage of patients achieved high-quality cleansing with oral sodium sulfate compared with sodium picosulfate plus magnesium citrate (both administered as split doses; $94.7 \%$ vs $85.7 \%$, respectively; $P=0.006)$. While the frequency of AEs was comparable between bowel preparations, nausea was reported by a significantly greater percentage of patients receiving oral sodium sulfate immediately prior to colonoscopy compared with the rate for sodium picosulfate plus magnesium citrate (44\% vs $27 \%, P=0.02$ ) [96]. Transient shifts in electrolyte and uric acid levels occurred in some patients with normal baseline levels immediately following split-dose administration of oral sulfate solution: high uric acid (23.5\%), low bicarbonate (12.7\%), high calcium (10.4\%), high bilirubin (8.5\%), low sodium (3.1\%), and high creatinine (1.9\%) [103].

Magnesium citrate is an over-the-counter hyperosmotic bowel preparation product with limited efficacy data [39]. A study of patients in a private-care setting who received bowel preparation the day before colonoscopy indicated that bowel cleansing was significantly better with magnesium citrate $(n=$ 140) compared with an oral sodium phosphate formulation (n $=160 ; P<0.001$ ) [119]. Excellent or good cleansing was reported in the right and left colon for $94 \%$ and $97 \%$, respectively, of patients who received magnesium citrate versus $73 \%$ and $89 \%$, respectively, of patients who received oral sodium phosphate [119]. However, magnesium citrate should not be used in older patients or those with kidney disease, due to the potential for magnesium toxicity, and current guidelines recommend against the routine use of magnesium citrate due to the limited efficacy data and the potential for AEs [39].

\section{Conclusions}

Colonoscopy decreases incidence and mortality of CRC. A variety of benchmarks exist to confirm high-quality cleansing in preparation for colonoscopy. Adequate bowel preparation is a central component of these quality benchmarks and can affect colonoscopy completeness, safety, and ADRs. Guidelines support the practice of split-dosing (2-day), with same-day dosing as an option to reduce the runway time (preparation-to-procedure time). High-quality cleansing of the proximal colon is critical for maximizing detection of flat lesions and serrated lesions, which have been implicated in the development of interval CRC. The selection of a bowel preparation agent is based on multiple product-related factors, including efficacy, safety, tolerability, volume, and ease of administration, in conjunction with patient history and preferences. It is critical that healthcare providers and patients recognize the importance of successful bowel preparation and maximize opportunities for its optimization with new developments in colon preparation formulations and administration.

\section{Acknowledgments}

Technical editorial and medical writing assistance were provided under the direction of the authors by Mary Beth Moncrief, PhD, and Sophie Bolick, PhD, Synchrony Medical Communications, LLC, West Chester, Pennsylvania, United States. Funding for this support was provided by Salix Pharmaceuticals.

\section{Competing interests}

Dr. Sharma is a consultant for Boston Scientific and Olympus Inc. Dr. Burke receives research support from Cancer Prevention Pharmaceuticals and Ferring Pharmaceuticals and serves as a consultant for Aries Pharmaceuticals Inc., Ferring Pharmaceuticals, and Salix Pharmaceuticals. Dr. Johnson serves as a consultant for Aries Pharmaceuticals Inc., WebMD, and HyGleaCare. Dr. Cash is a consultant for Salix Pharmaceuticals.

References

[1] American Cancer Society. Cancer facts \& figures 2019. Atlanta, GA: American Cancer Society; 2019: https://www.cancer.org/research/ cancer-facts-statistics/all-cancer-facts-figures/cancer-facts-figures2019.html [Accessed: 2019 July 9]

[2] Petrelli F, Tomasello G, Borgonovo K et al. Prognostic survival associated with left-sided vs right-sided colon cancer: a systematic review and meta-analysis. JAMA Oncol 2016; 3: 211-219

[3] American Cancer Society. Colorectal cancer facts \& figures 20172019. Atlanta, GA: American Cancer Society; 2017: https://www. cancer.org/content/dam/cancer-org/research/cancer-facts-and- 
statistics/colorectal-cancer-facts-and-figures/colorectal-cancerfacts-and-figures-2017-2019.pdf [Accessed: 2017 November 18]

[4] Winawer S], Zauber AG, Ho MN et al. Prevention of colorectal cancer by colonoscopic polypectomy. N Engl J Med 1993; 329: 1977-1981

[5] Zauber AG, Winawer S], O’Brien M] et al. Colonoscopic polypectomy and long-term prevention of colorectal-cancer deaths. N Engl J Med 2012; 366: 687-696

[6] Doubeni CA, Corley DA, Quinn VP et al. Effectiveness of screening colonoscopy in reducing the risk of death from right and left colon cancer: a large community-based study. Gut 2018; 67: 291-298

[7] Nishihara R, Wu K, Lochhead P et al. Long-term colorectal-cancer incidence and mortality after lower endoscopy. N Engl J Med 2013; 369: 1095-1105

[8] Brenner H, Chang-Claude J, Jansen L et al. Reduced risk of colorectal cancer up to 10 years after screening, surveillance, or diagnostic colonoscopy. Gastroenterology 2014; 146: 709-717

[9] Brenner $\mathrm{H}$, Hoffmeister $\mathrm{M}$, Arndt $\mathrm{V}$ et al. Protection from right- and left-sided colorectal neoplasms after colonoscopy: populationbased study. J Natl Cancer Inst 2010; 102: 89-95

[10] Singh H, Nugent Z, Demers AA et al. The reduction in colorectal cancer mortality after colonoscopy varies by site of the cancer. Gastroenterology 2010; 139: 1128-1137

[11] Baxter NN, Goldwasser MA, Paszat LF et al. Association of colonoscopy and death from colorectal cancer. Ann Intern Med 2009; 150: $1-8$

[12] Burke C. Evolving strategies for the prevention of colorectal cancer. Gastroenterol Hepatol 2017; 13: 2-10

[13] Simon K. Colorectal cancer development and advances in screening. Clin Interv Aging 2016; 11: 967-976

[14] Szylberg L, Janiczek M, Popiel A et al. Serrated polyps and their alternative pathway to the colorectal cancer: a systematic review. Gastroenterol Res Pract 2015; 2015: 1-7

[15] Brenner $H$, Jansen L, Ulrich $A$ et al. Survival of patients with symptom- and screening-detected colorectal cancer. Oncotarget 2016; 7: 44695-44704

[16] Kahi C], Imperiale TF, Juliar BE et al. Effect of screening colonoscopy on colorectal cancer incidence and mortality. Clin Gastroenterol Hepatol 2009; 7: 770-775

[17] Siegel RL, Miller KD, Jemal A. Cancer statistics, 2018. CA Cancer J Clin 2018; 68: 7-30

[18] Edwards BK, Ward E, Kohler BA et al. Annual report to the nation on the status of cancer, 1975-2006, featuring colorectal cancer trends and impact of interventions (risk factors, screening, and treatment) to reduce future rates. Cancer 2010; 116: 544-573

[19] Bibbins-Domingo K, Grossman DC, Curry S] et al. Screening for colorectal cancer: US Preventive Services Task Force recommendation statement. JAMA 2016; 315: 2564-2575

[20] Rex DK, Boland CR, Dominitz JA et al. Colorectal cancer screening: recommendations for physicians and patients from the U.S. MultiSociety Task Force on Colorectal Cancer. Am J Gastroenterol 2017; 112: 1016-1030

[21] Rex DK, Johnson DA, Anderson JC et al. American College of Gastroenterology guidelines for colorectal cancer screening 2009 [corrected]. Am J Gastroenterol 2009; 104: 739-750

[22] Wolf AMD, Fontham ETH, Church TR et al. Colorectal cancer screening for average-risk adults: 2018 guideline update from the American Cancer Society. CA Cancer J Clin 2018; 68: 250-281

[23] Siegel RL, Miller KD, Jemal A. Colorectal cancer mortality rates in adults aged 20 to 54 years in the United States, 1970-2014. JAMA 2017; 318: 572-574
[24] Siegel RL, Fedewa SA, Anderson WF et al. Colorectal cancer incidence patterns in the United States, 1974-2013. J Natl Cancer Inst 2017; 109: 1-6

[25] Bailey CE, Hu CY, You YN et al. Increasing disparities in the agerelated incidences of colon and rectal cancers in the United States, 1975-2010. JAMA Surg 2015; 150: 17-22

[26] Klabunde CN. Vital signs: colorectal cancer screening test use-United States, 2012. MMWR Morb Mortal Wkly Rep 2013; 62: 881-888

[27] Nayor J, Saltzman JR, Campbell EJ et al. Impact of physician compliance with colonoscopy surveillance guidelines on interval colorecta cancer. Gastrointest Endosc 2017; 85: 1263-1270

[28] Jones RM, Devers KJ, Kuzel AJ et al. Patient-reported barriers to colorectal cancer screening: a mixed-methods analysis. Am J Prev Med 2010; 38: 508-516

[29] Rex DK, Schoenfeld PS, Cohen J et al. Quality indicators for colonoscopy. Gastrointest Endosc 2015; 81: 31-53

[30] Jang JY, Chun H]. Bowel preparations as quality indicators for colonoscopy. World J Gastroenterol 2014; 20: 2746-2750

[31] Corley DA, Jensen CD, Marks AR et al. Variation of adenoma prevalence by age, sex, race, and colon location in a large population: implications for screening and quality programs. Clin Gastroenterol Hepatol 2013; 11: 172-180

[32] Kaminski MF, Regula J, Kraszewska E et al. Quality indicators for colonoscopy and the risk of interval cancer. N Engl J Med 2010; 362: 1795-1803

[33] Corley DA, Jensen CD, Marks AR et al. Adenoma detection rate and risk of colorectal cancer and death. N Engl J Med 2014; 370: 12981306

[34] Lieberman DA, Rex DK, Winawer S] et al. Guidelines for colonoscopy surveillance after screening and polypectomy: a consensus update by the US Multi-Society Task Force on Colorectal Cancer. Gastroenterology 2012; 143: 844-857

[35] Meester RG, Doubeni CA, Lansdorp-Vogelaar I et al. Variation in adenoma detection rate and the lifetime benefits and cost of colorectal cancer screening: a microsimulation model. JAMA 2015; 313 : 2349-2358

[36] Parmar R, Martel M, Rostom A et al. Validated scales for colon cleansing: a systematic review. Am J Gastroenterol 2016; 111: 197204

[37] Aronchick CA, Lipshutz WH, Wright SH et al. A novel tableted purgative for colonoscopic preparation: efficacy and safety comparisons with Colyte and Fleet Phospho-Soda. Gastrointest Endosc 2000 52: $346-352$

[38] Rostom A, Jolicoeur E. Validation of a new scale for the assessment of bowel preparation quality. Gastrointest Endosc 2004; 59: 482486

[39] Saltzman JR, Cash B. ASGE Standards of Practice Committe. et al. Bowel preparation before colonoscopy. Gastrointest Endosc 2015 81: 781-794

[40] Lai E], Calderwood AH, Doros G et al. The Boston Bowel Preparation Scale: a valid and reliable instrument for colonoscopy-oriented research. Gastrointest Endosc 2009; 69: 620-625

[41] Halphen M, Heresbach D, Gruss HJ et al. Validation of the Harefield Cleansing Scale: a tool for the evaluation of bowel cleansing quality in both research and clinical practice. Gastrointest Endosc 2013; 78 : $121-131$

[42] Gerard DP, Foster DB, Raiser MW et al. Validation of a new bowel preparation scale for measuring colon cleansing for colonoscopy: the Chicago Bowel Preparation Scale. Clin Transl Gastroenterol 2013 4: 1-11

[43] Calderwood AH, Jacobson BC. Comprehensive validation of the Boston Bowel Preparation Scale. Gastrointest Endosc 2010; 72: 686692 
[44] Hassan C, Fuccio L, Bruno M et al. A predictive model identifies patients most likely to have inadequate bowel preparation for colonoscopy. Clin Gastroenterol Hepatol 2012; 10: 501-506

[45] Kazarian ES, Carreira FS, Toribara NW et al. Colonoscopy completion in a large safety net health care system. Clin Gastroenterol Hepatol 2008; 6: 438-442

[46] Lebwohl B, Kastrinos F, Glick M et al. The impact of suboptimal bowel preparation on adenoma miss rates and the factors associated with early repeat colonoscopy. Gastrointest Endosc 2011; 73: 1207-1214

[47] Lebwohl B, Wang TC, Neugut Al. Socioeconomic and other predictors of colonoscopy preparation quality. Dig Dis Sci 2010; 55: 20142020

[48] Nguyen DL, Wieland M. Risk factors predictive of poor quality preparation during average risk colonoscopy screening: the importance of health literacy. J Gastrointestin Liver Dis 2010; 19: 369-372

[49] Froehlich F, Wietlisbach V, Gonvers JJ et al. Impact of colonic cleansing on quality and diagnostic yield of colonoscopy: the European Panel of Appropriateness of Gastrointestinal Endoscopy European multicenter study. Gastrointest Endosc 2005; 61: 378-384

[50] Harewood GC, Sharma VK, de Garmo P. Impact of colonoscopy preparation quality on detection of suspected colonic neoplasia. Gastrointest Endosc 2003; 58: 76-79

[51] Cohen LB. Advances in bowel preparation for colonoscopy. Gastrointest Endosc Clin N Am 2015; 25: 183-197

[52] Anderson JC, Baron JA, Ahnen DJ et al. Factors associated with shorter colonoscopy surveillance intervals for patients with low-risk colorectal adenomas and effects on outcome. Gastroenterology 2017; 152: 1933-1943 e1935

[53] Hillyer GC, Basch CH, Lebwohl B et al. Shortened surveillance intervals following suboptimal bowel preparation for colonoscopy: results of a national survey. Int J Colorectal Dis 2013; 28: 73-81

[54] Hendry PO, Jenkins JT, Diament RH. The impact of poor bowel preparation on colonoscopy: a prospective single centre study of 10,571 colonoscopies. Colorectal Dis 2007; 9: 745-748

[55] Aslinia F, Uradomo L, Steele A et al. Quality assessment of colonoscopic cecal intubation: an analysis of 6 years of continuous practice at a university hospital. Am J Gastroenterol 2006; 101: 721-731

[56] Bernstein C, Thorn M, Monsees K et al. A prospective study of factors that determine cecal intubation time at colonoscopy. Gastrointest Endosc 2005; 61: 72-75

[57] Bowles C], Leicester R, Romaya C et al. A prospective study of colonoscopy practice in the UK today: are we adequately prepared for national colorectal cancer screening tomorrow? Gut 2004; 53: 277283

[58] Nelson DB, McQuaid KR, Bond JH et al. Procedural success and complications of large-scale screening colonoscopy. Gastrointest Endosc 2002; 55: 307-314

[59] Rex DK, Imperiale TF, Latinovich DR et al. Impact of bowel preparation on efficiency and cost of colonoscopy. Am J Gastroenterol 2002; 97: $1696-1700$

[60] Kim WH, Cho YJ, Park JY et al. Factors affecting insertion time and patient discomfort during colonoscopy. Gastrointest Endosc 2000; 52: 600-605

[61] Robertson D], Lieberman DA, Winawer S] et al. Colorectal cancers soon after colonoscopy: a pooled multicohort analysis. Gut 2014; 63: 949-956

[62] Brenner H, Chang-Claude J, Seiler CM et al. Interval cancers after negative colonoscopy: population-based case-control study. Gut 2012; 61: 1576-1582

[63] le Clercq CM, Bouwens MW, Rondagh E] et al. Postcolonoscopy colorectal cancers are preventable: a population-based study. Gut 2014; 63: 957-963
[64] Arain MA, Sawhney M, Sheikh S et al. CIMP status of interval colon cancers: another piece to the puzzle. Am J Gastroenterol 2010; 105: 1189-1195

[65] Samadder N], Curtin K, Tuohy TM et al. Characteristics of missed or interval colorectal cancer and patient survival: a population-based study. Gastroenterology 2014; 146: 950-960

[66] Singh S, Singh PP, Murad MH et al. Prevalence, risk factors, and outcomes of interval colorectal cancers: a systematic review and metaanalysis. Am J Gastroenterol 2014; 109: 1375-1389

[67] Johnson DA, Barkun AN, Cohen LB et al. Optimizing adequacy of bowel cleansing for colonoscopy: recommendations from the US Multi-Society Task Force on Colorectal Cancer. Gastroenterology 2014; 147: 903-924

[68] Lasisi F, Rex DK. Improving protection against proximal colon cancer by colonoscopy. Expert Rev Gastroenterol Hepatol 2011; 5: 745-754

[69] Obuch JC, Pigott CM, Ahnen DJ. Sessile serrated polyps: detection, eradication, and prevention of the evil twin. Curr Treat Options Gastroenterol 2015; 13: 156-170

[70] Clark BT, Rustagi T, Laine L. What level of bowel prep quality requires early repeat colonoscopy: systematic review and meta-analysis of the impact of preparation quality on adenoma detection rate. Am J Gastroenterol 2014; 109: 1714-1723

[71] Anderson JC, Butterly LF, Robinson CM et al. Impact of fair bowe preparation quality on adenoma and serrated polyp detection: data from the New Hampshire colonoscopy registry by using a standardized preparation-quality rating. Gastrointest Endosc 2014; 80: 463470

[72] Chokshi RV, Hovis CE, Hollander T et al. Prevalence of missed adenomas in patients with inadequate bowel preparation on screening colonoscopy. Gastrointest Endosc 2012; 75: 1197-1203

[73] Hong SN, Sung IK, Kim JH et al. The effect of the bowel preparation status on the risk of missing polyp and adenoma during screening colonoscopy: a tandem colonoscopic study. Clin Endosc 2012; 45: 404-411

[74] Sherer EA, Imler TD, Imperiale TF. The effect of colonoscopy preparation quality on adenoma detection rates. Gastrointest Endosc 2012; 75: 545-553

[75] Wong MC, Ching JY, Chan VC et al. Determinants of bowel preparation quality and its association with adenoma detection: a prospective colonoscopy study. Medicine (Baltimore) 2016; 95: e2251

[76] Guo X, Yang Z, Zhao L et al. Enhanced instructions improve the quality of bowel preparation for colonoscopy: a meta-analysis of randomized controlled trials. Gastrointest Endosc 2017; 85: 90-97 e96

[77] Mamula P, Adler DG, Conway JD et al. Colonoscopy preparation. Gastrointest Endosc 2009; 69: 1201-1209

[78] Smith SG, von Wagner C, McGregor LM et al. The influence of health literacy on comprehension of a colonoscopy preparation information leaflet. Dis Colon Rectum 2012; 55: 1074-1080

[79] Cipolletta L, Rotondano G. Patient-friendly bowel preparation for colonoscopy - another brick in the wall? Dig Liver Dis 2013; 45: $16-17$

[80] Kilgore TW, Abdinoor AA, Szary NM et al. Bowel preparation with split-dose polyethylene glycol before colonoscopy: a meta-analysis of randomized controlled trials. Gastrointest Endosc 2011; 73: $1240-1245$

[81] Martel M, Barkun AN, Menard C et al. Split-dose preparations are superior to day-before bowel cleansing regimens: a meta-analysis. Gastroenterology 2015; 149: 79-88

[82] Horton N, Garber A, Hasson H et al. Impact of single- vs. split-dose low-volume bowel preparations on bowel movement kinetics, patient inconvenience, and polyp detection: a prospective trial. Am J Gastroenterol 2016; 111: 1330-1337 
[83] Avalos DJ, Castro FJ, Zuckerman MJ et al. Bowel preparations administered the morning of colonoscopy provide similar efficacy to a split-dose regimen: a meta analysis. J Clin Gastroenterol 2017; 52: 859-868

[84] Seo EH, Kim TO, Park M] et al. Optimal preparation-to-colonoscopy interval in split-dose PEG bowel preparation determines satisfactory bowel preparation quality: an observational prospective study. Gastrointest Endosc 2012; 75: 583-590

[85] Gandhi K, Tofani C, Sokach C et al. Patient characteristics associated with quality of colonoscopy preparation: a systematic review and meta-analysis. Clin Gastroenterol Hepatol 2018; 16: 357-369 e310

[86] Lee DW, Koo JS, Kang S et al. Association between bowel habits and quality of bowel preparation for colonoscopy. Medicine (Baltimore) 2017; 96: e7319

[87] Menees SB, Kim HM, Wren P et al. Patient compliance and suboptimal bowel preparation with split-dose bowel regimen in average-risk screening colonoscopy. Gastrointest Endosc 2014; 79: 811-820

[88] Chan WK, Saravanan A, Manikam J et al. Appointment waiting times and education level influence the quality of bowel preparation in adult patients undergoing colonoscopy. BMC Gastroenterol 2011; 11: 86

[89] Davis TC, Hancock J, Morris J et al. Impact of health literacy-directed colonoscopy bowel preparation instruction sheet. Am J Health Behav 2017; 41: 301-308

[90] Harrison NM, Hjelkrem MC. Bowel cleansing before colonoscopy: balancing efficacy, safety, cost and patient tolerance. World J Gastrointest Endosc 2016; 8: 4-12

[91] Harewood GC, Wiersema M], Melton L] et al. A prospective, controlled assessment of factors influencing acceptance of screening colonoscopy. Am J Gastroenterol 2002; 97: 3186-3194

[92] Young LE, Sacks NC, Cyr PL et al. Comparison of claims data on hospitalization rates and repeat procedures in patients receiving a bowel preparation prior to colonoscopy. SAGE Open Med 2017; 5: $1-8$

[93] Lichtenstein GR, Cohen LB, Uribarri J. Review article: Bowel preparation for colonoscopy - the importance of adequate hydration. Aliment Pharmacol Ther 2007; 26: 633-641

[94] Bucci C, Rotondano G, Hassan C et al. Optimal bowel cleansing for colonoscopy: split the dose! A series of meta-analyses of controlled studies Gastrointest Endosc 2014; 80: 566-576 e562

[95] Siddiqui AA, Yang K, Spechler S] et al. Duration of the interval between the completion of bowel preparation and the start of colonoscopy predicts bowel-preparation quality. Gastrointest Endosc 2009; 69: 700-706

[96] Rex DK, DiPalma JA, McGowan J et al. A comparison of oral sulfate solution with sodium picosulfate: magnesium citrate in split doses as bowel preparation for colonoscopy. Gastrointest Endosc 2014; 80: $1113-1123$

[97] Martens P, Bisschops R. Bowel preparation for colonoscopy: efficacy, tolerability and safety. Acta Gastroenterol Belg 2014; 77: 249-255

[98] Sharara Al, Abou Mrad RR. The modern bowel preparation in colonoscopy. Gastroenterol Clin North Am 2013; 42: 577-598

[99] GoLYTELY (polyethylene glycol 3350 and electrolytes oral solution) [package insert]. Braintree, MA: Braintree Laboratories, Inc.; 2013

[100] NuLYTELY (polyethylene glycol 3350, sodium chloride, sodium bicarbonate and potassium chloride for oral solution) [package insert]. Braintree, MA: Braintree Laboratories, Inc.; 2013

[101] MoviPrep (polyethylene glycol 3350, sodium sulfate, sodium chloride, potassium chloride, sodium ascorbate, and ascorbic acid for oral solution) [package insert]. Bridgewater, N]: Salix Pharmaceuticals Inc.; 2016

[102] Plenvu (polyethylene glycol 3350, sodium ascorbate, sodium sulfate, ascorbic acid, sodium chloride and potassium chloride for oral solution) [package insert]. Amsterdam, The Netherlands: Norgine B. V.; 2019

[103] Suprep Bowel Prep Kit (sodium sulfate, potassium sulfate, and magnesium sulfate) oral solution [package insert]. Braintree, MA: Braintree Laboratories, Inc.; 2010

[104] Prepopik (sodium picosulfate, magnesium oxide, and anhydrous citric acid) for oral solution [package insert]. Parsippany, N]: Ferring Pharmaceuticals Inc.; 2012

[105] Osmoprep (sodium phosphate monobasic monohydrate, USP and sodium phosphate dibasic anhydrous, USP) Tablets [package insert]. Bridgewater, NJ: Salix Pharmaceuticals, Inc.; 2016

[106] Clenpiq (sodium phosphate monobasic monohydrate, USP and sodium phosphate dibasic anhydrous, USP) Tablets [package insert]. Parsippany, NJ: Ferring Pharmaceuticals, Inc.; 2017

[107] MiraLAX (polyethylene glycol 3350, powder for solution, osmotic laxative) [package insert]. Boca Raton, FL: Bayer; 2019

[108] Chisholm S, Patel AM, Tierney WM et al. Adult bowel preparations for colonoscopy. J Okla State Med Assoc 2015; 108: 311-317

[109] Rutherford CC, Calderwood AH. Update on bowel preparation for colonoscopy. Curr Treat Options Gastroenterol 2018; 16: 165-181

[110] DiPalma JA, Marshall JB. Comparison of a new sulfate-free polyethylene glycol electrolyte lavage solution versus a standard solution for colonoscopy cleansing. Gastrointest Endosc 1990; 36: 285-289

[111] Davis GR, Santa Ana CA, Morawski SG et al. Development of a lavage solution associated with minimal water and electrolyte absorption or secretion. Gastroenterology 1980; 78: 991-995

[112] DiPalma JA, Brady CE 3rd. Colon cleansing for diagnostic and surgical procedures: polyethylene glycol-electrolyte lavage solution. Am J Gastroenterol 1989; 84: 1008-1016

[113] Hillyer GC, Lebwohl B, Basch CH et al. Split dose and MiraLAX-based purgatives to enhance bowel preparation quality becoming common recommendations in the US. Therap Adv Gastroenterol 2013; 6: $5-14$

[114] Xie Q, Chen L, Zhao F et al. A meta-analysis of randomized controlled trials of low-volume polyethylene glycol plus ascorbic acid versus standard-volume polyethylene glycol solution as bowel preparations for colonoscopy. PLoS One 2014; 9: e99092

[115] Bisschops R, Manning J, Clayton LB et al. Colon cleansing efficacy and safety with $1 \mathrm{~L}$ NER1006 versus $2 \mathrm{~L}$ polyethylene glycol + ascorbate: a randomized phase 3 trial. Endoscopy 2019; 51: 60-72

[116] DeMicco MP, Clayton LB, Pilot J et al. Novel $1 \mathrm{~L}$ polyethylene glycolbased bowel preparation NER1006 for overall and right-sided colon cleansing: a randomized controlled phase 3 trial versus trisulfate. Gastrointest Endosc 2018; 87: 677-687

[117] Schreiber S, Baumgart DC, Drenth JPH et al. Colon cleansing efficacy and safety with $1 \mathrm{~L}$ NER 1006 versus sodium picosulfate with magnesium citrate: a randomized phase 3 trial. Endoscopy 2019; 51: $73-$ 84

[118] Yang HJ, Park SK, Kim JH et al. Randomized trial comparing oral sulfate solution with 4-L polyethylene glycol administered in a split dose as preparation for colonoscopy. J Gastroenterol Hepatol 2017; 32: $12-18$

[119] Berkelhammer C, Ekambaram A, Silva RG. Low-volume oral colonoscopy bowel preparation: sodium phosphate and magnesium citrate. Gastrointest Endosc 2002; 56: 89-94 